\title{
The European imbalances: Competitiveness and economic policy in a non-optimal monetary union and a global recession
}

\author{
Ferran Brunet \\ Universitat Autònoma de Barcelona
}

\begin{abstract}
The macroeconomic disequilibria of some European Union Member States steadily grew in the European monetary union spoiled by the crisis. The euroimbalances result from (i) productivity deficits and macroeconomic disequilibria such as underinvestment and overconsumption, (ii) structural disequilibria of an inflexible labour market such as a low employment rate and high unemployment, (iii) deficits in competition and overregulation, and (iv) an unruly policy mix, which is especially the case in certain Mediterranean countries. All of these imbalances and limitations greatly hinder the performance of the deficit countries, such us that of the europeriphery, and of the entire Union.

This paper shall analyse the dynamics of the euroimbalances and show their root causes to be found in structural disequilibria. While heavily accentuated by a non-optimal European monetary union, the growing euroimbalances are provoking both distrust among some countries and a huge crisis for the euro, not to mention the possibility of the public and private debt crash turning into in a lengthy recession. The fiesta long over, a well-developed European economic governance can strengthen cooperation and plot out a course for structural reforms to deal with the challenges Europe faces in order to gain greater stability, competitiveness and welfare. The need for Europe is a tangible one for the sustained progress of many Member States, as well as a means to better manage the economic and political systemic risks to the European Union as a whole.
\end{abstract}

Keywords: European imbalances, competitiveness, economic policy, European Union, European countries, crisis, structural reforms, economic governance.

JEL classification: E21, E32, F15, F41, O16.

\section{Resumen}

Espoleados por la crisis, los desequilibrios macroeconómicos han crecido fuertemente en la Unión Europea, especialmente entre los Estados miembros de la eurozona. Los llamados euroimbalances son fruto de (i) un déficit de productividad y de desequilibrios como la infrainversión y el sobreconsumo, (ii) desequilibrios estructurales como un mercado de trabajo inflexible, con baja tasa de empleo y altísima tasa de paro, (iii) déficit en la competencia y sobreregulación, y (iv) políticas económicas díscolas, por ejemplo en algunos países mediterráneos. Estos desequilibrios limitan gravemente la competitividad de muchos países europeos, señaladamente los de la europeriferia, y al conjunto de la Unión.

Este artículo analiza la dinámica de los euroimbalances y muestra su fundamento en los desequilibrios estructurales. Acentuado por el carácter no óptimo de la unión monetaria europea, los crecientes imbalances provocaron desconfianza hacia ciertas economías y una aguda crisis en el eurosistema, por no mencionar la posibilidad de un crack de deuda privada y pública y del sistema financiero, por ahora conjurado en forma de gran recesión. Terminada la fiesta, la nueva gobernanza económica europea podrá intensificar la cooperación y las reformas estructurales para enfrentar así los retos de Europa y ganar en estabilidad, competitividad y bienestar. Para 
el progreso de muchos Estados miembros, así como para preservar la propia Unión Europea, es tangible la necesidad de Europa.

Palabras clave: Desequiibrios europeos, competitividad, policía económica Union Europea, países europeos crisis reformas estructurales, gobernanza económica.

Clasificación JEL: E21, E32, F15, F41, O16.

\section{Introduction}

The European imbalances (EIB) are throwing the structural conditions, the competitiveness and the economic policy choices of the European Union (EU) Member States (MS) into stark relief. The economic crisis is doing just the same for the EIB, the shortcomings of EU economic governance and the inability of the deficit-ridden MS to compete in a context of economic integration in a non-optimal monetary union.

Despite the global position of the EU, some -of the MS are developing huge financial imbalances in commerce and capital. The current account (CA), the public deficit (PD) and other financial and structural imbalances are large and evergrowing. The historic catching-up process appears to have stalled and the internal differences and gaps are generating huge deficits financed by credit and debt, which notoriously favour persistent bubbles (European Commission. Directorate-General for Economic and Financial Affairs, 2016; IMF, 2016a).

The euro area (EA) is suffering from enormous constraints and is running equally high risks, something which is especially tragic for the Mediterranean MS: immobility of labour, inflexibility of salaries, deficits in competition and in regulation quality, non-cooperative policy mix and non-structural reforms. Thus the equilibrium rests on quantities such as unemployment and the low employment rate which undermine productivity and economic performance. The euro coverage has financed the EIB and the resulting deficits, postponing structural reforms that could fine-tune the system and improve performance.

The EIB and the unruly MS are putting the European integration process at risk. However, they can also push the EU and its MS to face their structural challenges: competitiveness, delocation, and ageing. The shortcomings of EU governance are adding instability to the systemic risks and the need for Europe has never been more evident -it is clearly the way to avoid an economic collapse. The moment has come for a change of quality, a progression toward a new European economic policy to set the MS and the entire EU on a more prudent course of action.

\section{The Imbalance Analyses}

In recent decades, a few keen and incisive analyses which mixed concepts and measure were developed and applied to economic current problems such as potential output, the imbalanced dynamics between the United States (US) and China with regards to deficits and surpluses, and generational accounts (Bergsten, 2010; Ano- 
nymous, 2010; IMF, 2016a). Nevertheless, the analysis of the foreign CA and of the balance of payments (BOP) also remains a must. In fact, analyses on foreign balance lay the foundations of economics as we know it, especially the debate on the impact of gold entries on the fair price of goods, as Joseph Schumpeter has shown.

\subsection{Linking concepts with measures: Balance sheet and financial imbalances}

These analyses mix:

i) Concepts and measures, quality and quantity -key for greater knowledge.

ii) Elements and totality, plus the entities and flows which connect them.

iii) Intellectual purposes with practical and interventional aims.

iv) Space (the totality and the parts organized by states, currency or custom areas, as well as by other political, economic and social criteria) and time.

v) Structure (static features, degree) and dynamics (transformation, change).

vi) The registering of most of the items and the evaluation of those remaining.

vii) Flows during a period and stocks at any given moment; the difference in the stocks between two given moments as the net worth, a surplus or a deficit, a capacity for net lending or a necessity for net borrowing.

All these applied economic approaches have favoured synchronised and diachronic analyses as they have the greater understanding of the individual cases and the comparisons. In accountancy, all of the imbalances are balanced out, thus any disequilibrium is formal because the surplus/deficit generates a capacity / necessity for finance. All of the 'disequilibria' are balanced by a placement (if it is a surplus) or by a credit (if it is a deficit). These interconnected operations balance out the system and permit its existence, continuity and reproduction. Therefore, intellectual and policy interests make themselves known through Figure 1.

- The size of the balances, surpluses and deficits, their causes as well as their impacts, plus what provides the conditions for the flows.

- What the differences between balances in different moments or in a moment between balances of different entities are.

The comparative analysis is supported by cognitive and policy interests responding to questions as to what could be the reason for differences among the elements of a balance, or the root causes of gaps and their tendencies. Except by accident, all balance sheets are materially imbalanced: it occurs quite regularly that the sum of all revenues is not equal to the sum of all payments. In cash operations, revenues need to be higher than payments, but in operations including explicit or implicit credit, the inverse is not only possible but is common practice. Then there are imbalance payments which 
FIGURE 1

THE EUROPEAN IMBALANCES FRAMEWORK

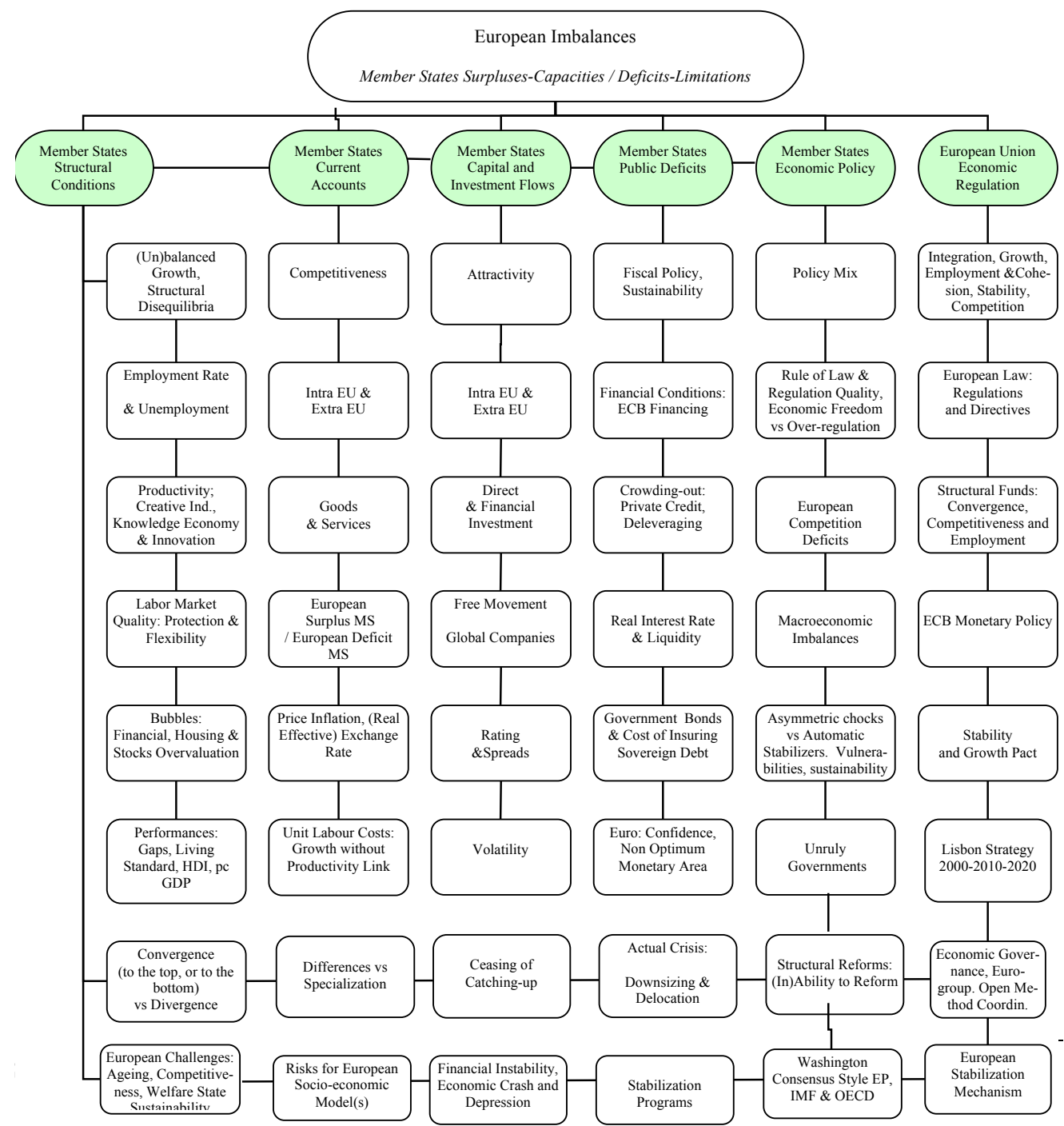

SOURCE: Author conception based on this research. 
balance the balance sheet. ${ }^{1}$ In accounting, a balance is a sheet of all the elements of an entity upon which are detailed both their origin and their application. In this sense, all balances are balanced out: the balance sheet is a register of every source as well as of every destination of the resources managed by a body during a period. The balances are initially imbalanced, producing financial payments to the surplus or to the deficits, and then are finally balanced. The principles of accountability can be applied to any matter: from the traditional micro-level of the revenues and expenditures of an enterprise to the macroeconomic accounts or the energy-balances of a territory. Moreover, many reductions and extensions of the accountability forms have been developed, from demographics to cost-benefit analysis (see Figure 2, next page).

\subsection{Imbalances: Conditions, consequences and policies}

There are considerable benefits to be had in making analyses of the CA (imports and exports of goods and services) and the other BOP elements (transfers and capital flows, reserve variations. especially of the dynamics of the imbalance. The analytical and policy interests are the conditions, causes, consequences and means of governance of the sustained IB, as follows:

I. How are the financial deficits financed and then sustained? One EIB, in commercial deficit for example, can balance another EIB such as a capital surplus.

II. What are the origins of the CA EIB? What are the joint sources and what are the structural sources? Which EIB are the result of an unbalanced exchange rate, which are the result of economic policy The consequences of the different origins of the EIB are serious: the prospects for the EIB vary greatly, as do the capacities of balancing the IB, not to mention the time needed for such a task. Reversing the CA and BOP EIB and managing the exchange rate have limited or transitory effects -changing the structural conditions is not immediately within the reach of policy-makers.

III. What are the immediate and medium-term impacts of the large EIB? The immediate is the EIB are financed and the impact puts strain upon the financial capacity of the borrower, sometimes putting the lender at risk too. Longerterm, the EIB go together with structural deficits and competitiveness gaps to heavily influence employment and unemployment rates.

${ }^{1}$ The OECD (2016a) displays 162 terms related to balance. We retain this: "Balance sheet: A balance sheet is a statement, drawn up at a particular point in time, of the values of assets owned and of liabilities outstanding), The balancing item is called net worth), In national accounts a balance sheet is drawn up for sectors, the total economy and the rest of the world), For a sector the balance sheet shows the value of all assets -produced, non-produced and financial- and liabilities and the sector's net worth), For the total economy the balance sheet provides as balancing item what is often referred to as national wealth: the sum of non-financial assets and net financial assets with respect to the rest of the world" (Ibid., 214). The imbalance is not defined exactly but it appears in other definitions as "direct financing of payments imbalances" and as "financial imbalances". 
FIGURE 2

EUROPEAN IMBALANCES:

ACCUMULATING DEFICITS - THE TRIPLET DEFICIT SKYLINE

Panel A: 2010

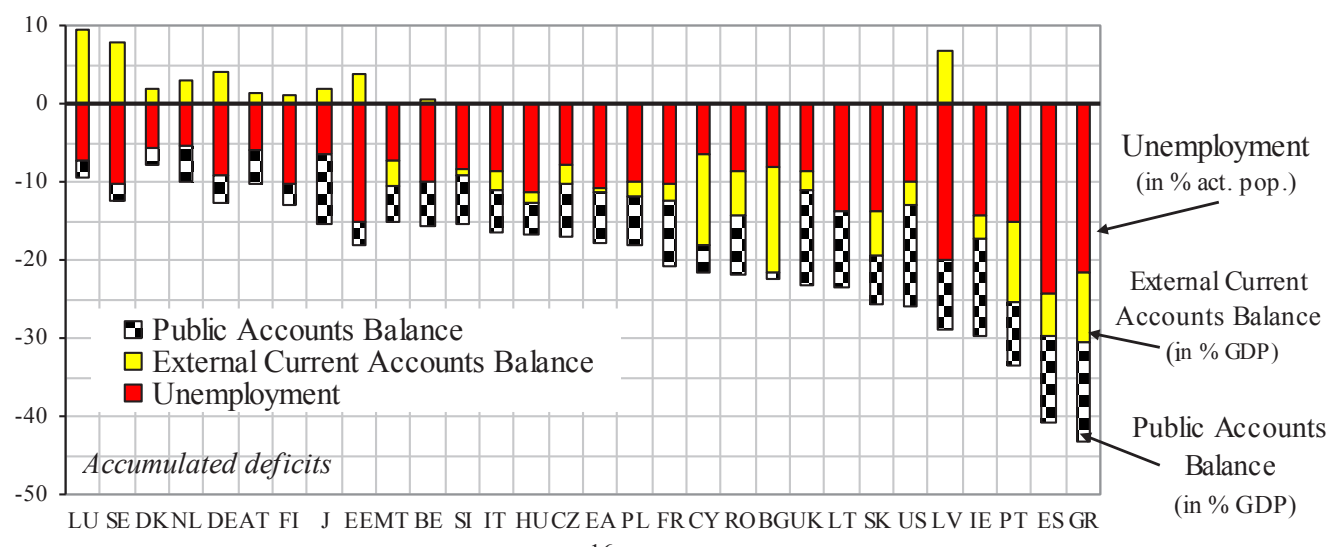

16

Panel B: 2015

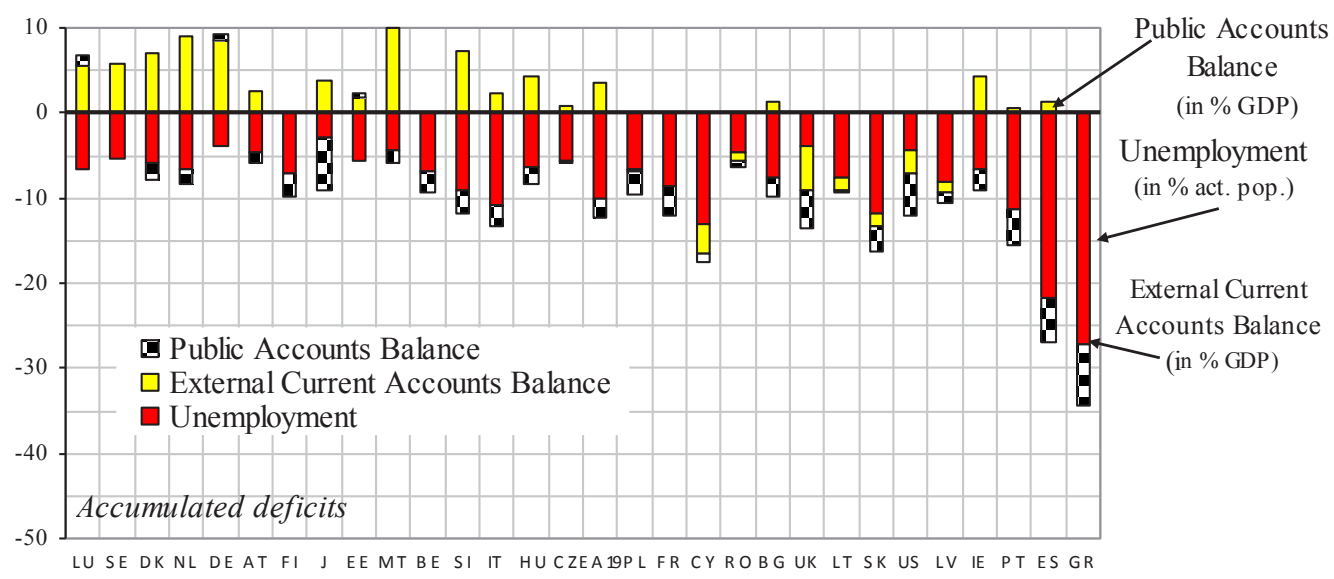

SOURCE: Elaboration on data from AMECO (2016), Eurostat (2016a) and OECD (2016b).

IV. How are the payment imbalances to be managed? There are two options: i) the countries with a surplus have an interest in enlarging it with a view to maximizing its benefits; and ii) the countries with deficit have an interest in reducing it with a view to minimizing its cost.

As the balances of private enterprises, macro-balances show the combined results of the market and of the regulations, both consequences of interactions in which no single agent has overwhelming power. 
FIGURE 3

UNEMPLOYMENT:

\section{LABOUR MARKETS DISEQUILIBRIA, LABOUR FORCE OVER-PROTECTION} AND NON-MOBILITY

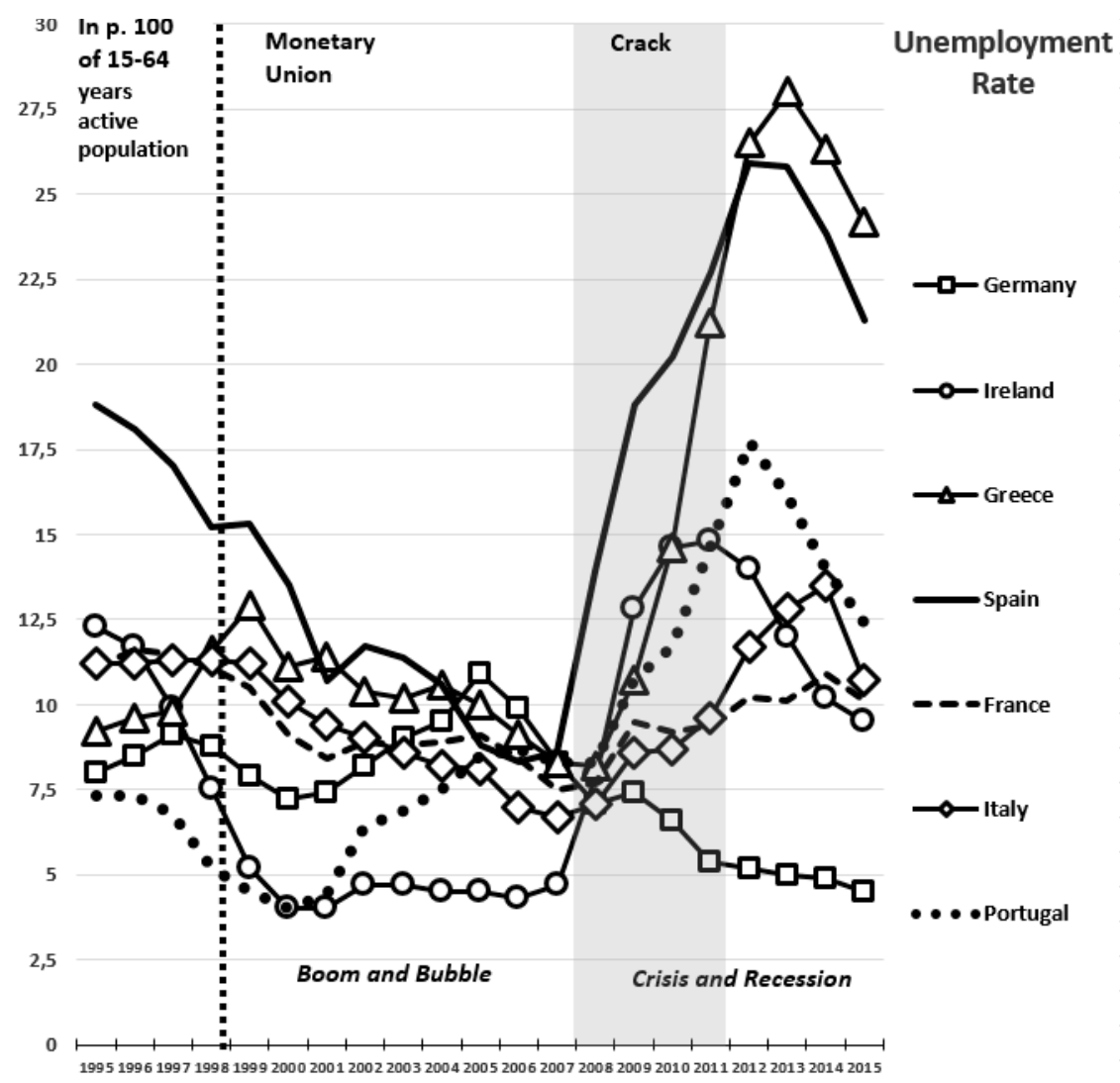

SOURCE: Elaboration on data from AMECO (2016), Eurostat (2016a), and OECD (2016b).

\subsection{The global imbalances}

The analyses of global imbalances were developed in light of the fact that the US deficits on CA and the PD were linked (twin deficits) and both were financed mainly by China, the new global creditor. This was the way in which the incredible US CA and PD were provoked and sustained: the surpluses obtained by China from commerce were financing US government deficits.

The three main explanations for the US-China EIB are: the relative competitiveness; the exchange rate between the renminbi and the dollar; and the twin facts of the US' under investment/over consumption and China's over investment/under 
consumption. Dialectic of interdependence and a simile of symbiosis can be read in the imbalances of the US and of China. ${ }^{2}$

A far cry from the huge global deficit of the US, the EU has had positive global $\mathrm{CA}$ and capital accounts; though in recent years the situation has changed and a CA deficit of 27,000 million euro has been accumulated, despite a surplus in services of 14,000 million euro (The Economist, 2010; Brunet, 2012; Eurostat, 2016; and FedStats, 2016). The EA and the EU15 present better balances. The crisis has indeed impaired trade and balances.

\section{European imbalances and deficits}

Foreign and public accounts are the main EIB. However, other economic imbalances such as unemployment, inflation costs or bubbles are heavy contributors and are sometimes their root causes. This makes for a complex malfunction which could prove difficult to rectify, especially regarding its social and politics implications. Here there is a special need for Europe.

\subsection{Imbalances, deficits and differences}

One classical approach is to apply account-balancing principles to different matters: balances of population, generations, energy or materials. Due to the limitations in the rules or to the availability of data, these analyses are not to be considered proper means of balancing, despite their inherent power. Thus, to continue the balance analyses one must embark upon the analyses of the deficits, the gaps and the differences (see Figure 1). Here there are four basic and frequently-referred-to imbalances:

- Foreign deficit as a CA imbalance (see next section).

- PD is the general government accounts imbalance, the gap between the government's current revenues and expenditures. It is balanced or financed by the settlement of public debt.

- Unemployment is a labour market imbalance due to an adjustment not by prices (wages. but by quantities (unemployed workers).

- Inflation of prices shows disequilibrium in the financial market between the quantity of money and the volume of GDP.

${ }^{2}$ Below we see the inverse condition for the EIB: In the euro zone the exchange rate is not so much an influencing factor as is the un/competitiveness of the deficit/surplus MS, and the fact there is more opposition than symbiosis), However, the tendencies towards over/under consumption/investment can also be the case for the EIB. 
The first two of these structural imbalances are really imbalance payments. However, the two other non-exact imbalances are matters in which the direct use of accounting principles is nonsense. When the analysis uses comparisons on the levels of an indicator, the concepts of gap and deficit are used; for example, the gap in productivity (Conference Board and Groningen Growth and Development Centre. 2016) between two economies, or the competition deficit (Brunet, 2010, 2013 and 2015) of one economy compared to another.

\section{FIGURE 4}

EXTERNAL CURRENT ACCOUNTS IMBALANCES: EUROCENTRE AND EUROPERIPHERY DYNAMICS

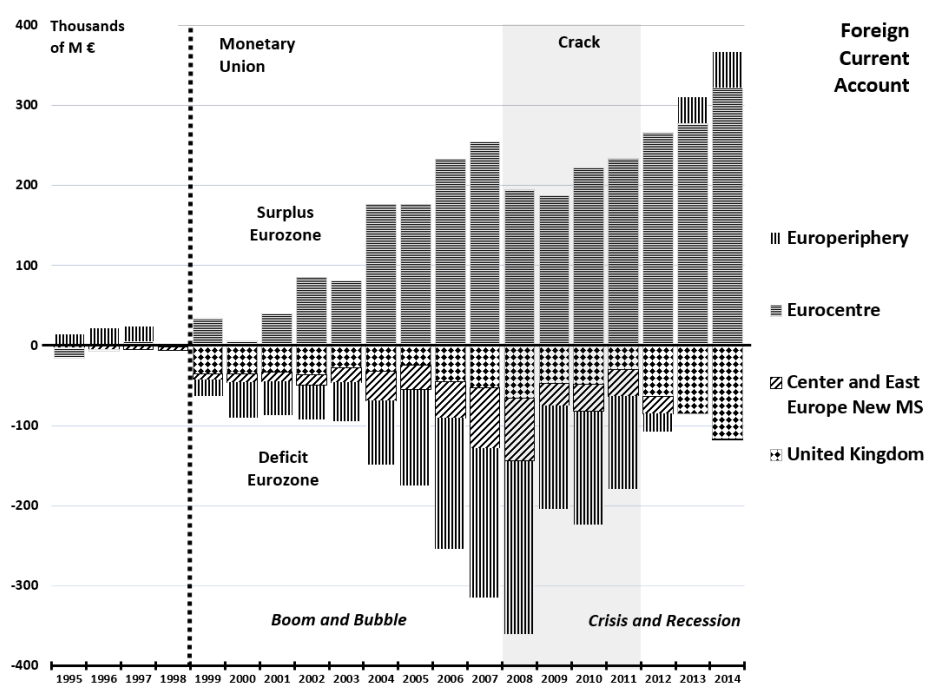

SOURCE: Elaboration on data from AMECO (2016), Eurostat (2016a), and OECD (2016b).

\subsection{Structural disequilibrium I: The European CA imbalances - Surplus and deficit MS - Nordic \& Central and Mediterranean \& Eastern MS}

In point of view of the EU, the trade of goods by the MS is both internal (dispatches and arrivals) and external (imports and exports). ${ }^{3}$ The internal and external trade of goods/services and the accounts of transfers and capital show the degree of integration with the EU and with the rest of the world. In the EU, internal trade is around $17 \%$ of the GDP and external around $11 \%$; for services the quotas are respectively 4,6 and 4,0\%. These figures are one-third higher in the EA MS. Depending on the size and development of the country, the direct investment inflows

\footnotetext{
${ }^{3}$ In the EIB analyses, the level taken into account is that of MS. Regional CA requires enormous estimations that limit the quality of the results.
} 
and outflows range from 3 to $30 \%$ of the GDP (Blanchard and Ferretti, 2009; and OECD 2015b). Regarding CA, there are two groups of countries:

- CA surplus MS: Austria, Belgium, Denmark, Estonia, Finland, Germany, Latvia, Luxembourg, Netherlands and Sweden.

- CA deficit MS: Bulgaria, Cyprus, Czech Republic, France, Greece, Hungary, Ireland, Italy, Lithuania, Malta, Poland, Portugal, Romania, Slovakia, Slovenia, Spain and United Kingdom (see Figures 2 and 4).

Most of the surplus MS are from Nordic and Central Europe, while most of the deficit MS are Mediterranean and in-transition. This is also the case for internal trade:

- Internal trade surplus MS: Belgium, Czech Republic, Denmark, Germany, Ireland, Luxembourg, Netherlands, Hungary, Poland and Slovakia.

- Internal trade deficit MS: Bulgaria, Estonia, Greece, Spain, France, Italy, Cyprus, Latvia, Lithuania, Malta, Austria, Portugal, Romania, Slovenia, Finland, Sweden and United Kingdom (see Figure 2).

The trade of services is producing a growing but limited quota of credits and debits, around one-quarter of the total CA.

\subsection{Structural disequilibrium II: The European MS public deficits - From over-intervention to the euro crash}

Both in 2010 and 2015all EU MS had a PD as we can see in Figure 2 (and see below the Figure 5 for the PD dynamics). The PD reveals the exact synthesis of economic policy choices, in particular in fiscal policy, and the macroeconomic conditions. In the past years of crisis, the pressures on revenues and expenditures caused the surpluses to turn into deficits. In point of view of the market, this is a key economic imbalance as a global market exists because of it -the sovereign public debt. Inside a monetary union, the financing of public budget with debt issue in the common currency can have two major impacts: a crowding-out effect on public and private credit, and an undermining of the credibility of all involved.

Now we see that the shoring-up of the PD and debt, respectively making for $3 \%$ and $60 \%$ of the GDP, is a condition for a MS holding membership of the eurozone, as well as being key for economic governance and cooperation between EA members as established by the Stability and Growth Pact (European Commission. DirectorateGeneral for Economic and Financial Affairs, 2008 and 2016; and World Bank, 2016a).

The European financial crash is due to the markets' appreciation of the capacities of some EA MS to reimburse their public debt. It follows that the mechanism of financial stabilization established by the Council of Economy and Finance on 9 May 2010 is quite an important moment in the development of the EU. (European Union, 2010). 
FIGURE 5

\section{PUBLIC SECTOR IMBALANCES: EXPLOSION DURING THE CRISIS}

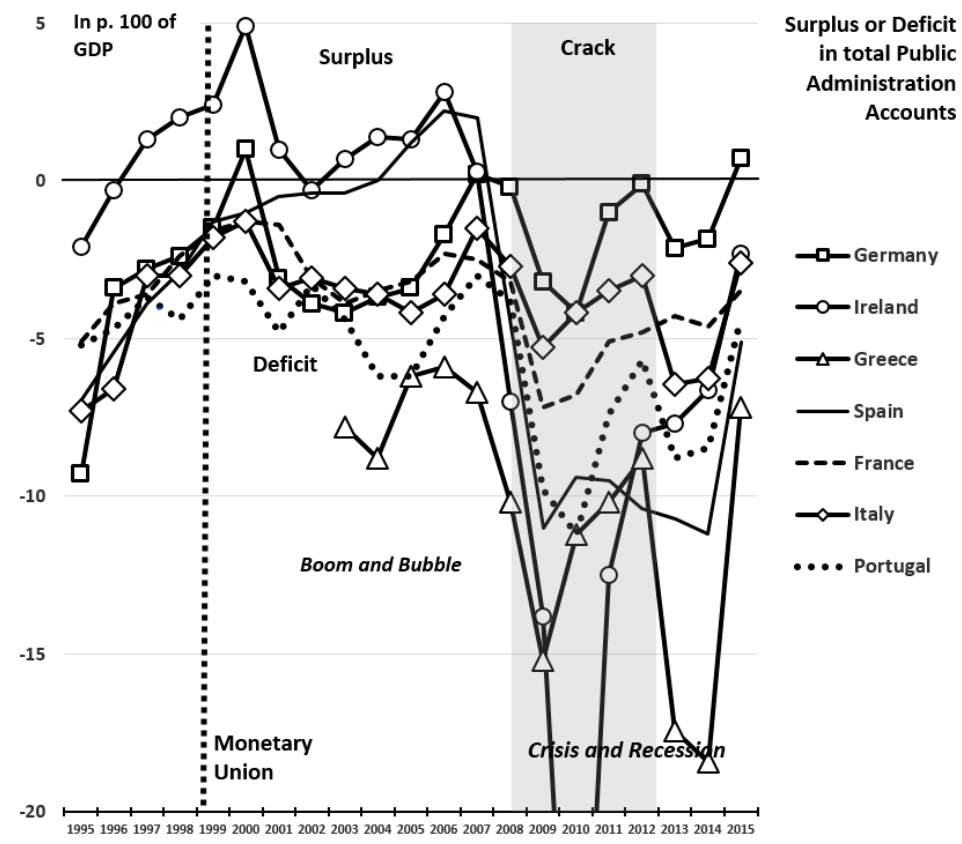

SOURCE: Elaboration on data from AMECO (2016), Eurostat (2016a) and OECD (2016b).

\subsection{Structural disequilibrium III: Limited current price inflation and interest rates, high labour unit costs, real effective exchange rate, excess of liquidity, high indebtedness and leveraging, bubbles... Finance instability and crash}

Finance is an essential ingredient in the current economic disequilibrium: the financial payments balance the imbalances of the balance of payments of the EA and of the MS which still possess an independent currency. Financial phenomena are not only part of the economic disequilibrium but are also an engine for it.

The financial aspects usually considered in relation to the CA balances are the exchange rate, costs and prices. In the EIB dynamics of the nominal and real effective exchange rate, labour unit costs and the relative inflation are determining factors. We can see this on Figure 2. The MS with lower/higher growth in unit labour cost are also those that have the highest CA surplus/deficits, and the inverse. The financial conditions and the monetary policy determined the low interest rates so characteristic of the last decade. This had two impacts on the EIB: a limited current price inflation, reducing the real effective exchange movements, and a means to finance trade and investments, impacts that both favoured transactions and indebtedness. 
The liquidity introduced into the financial markets, before and after the financial crash, has provoked and nourished the considerable bubbles in housing prices and activity (International Monetary Fund, 2016b). financial activities and stock markets. Correspondingly, large debt exists in private enterprises,

households, financial intermediaries and governments. ${ }^{4}$ The public debt is more sensitive, in particular that of the euro area MS, because of the impossibility of currency-adjustment. The exchange risk has been decreasing for these MS, as has the cost of their debt. But for the other MS of the EA, the risk of contagion has now increased. For an evaluation of the links between the EU MS in debt ownership, see Figures 2 and 3 below. For the MS with bigger EIB, net lending (for the MS with surpluses) or borrowing (for the MS with deficits) is higher, as can be seen below:

- German corporations (included financial entities) are producing a net lending of around $+2-3 \%$ of the GDP and the households of around $+4-6 \%$ (Eurostat, 2016).

- Spanish corporations (included financial entities) are producing a net borrowing of around $-6-8 \%$ of the GDP and the households of around $-3 \%$.

Corporate leverage is at 298\% (ratio of debt related to value added) in Spain and at $121 \%$ in Germany. There is a strong correlation between the CA deficits and the net borrowing for Spain, France, Italy and Portugal, and between the CA surpluses and the net lending of Germany, Netherlands and Austria (European Commission. Directorate General for Economic and Financial Affairs, 2016).

Germany is the net exporter of capital (13\% of total world. Spain, Italy, Greece and the UK are importers (respectively of 9,8\%, 4,7\%,3,3\% and 2,9\%) (International Monetary Fund, 2016a: 161).

The divergence of private financial accounts is complemented by public net deficits and net borrowing in all of the EA and EU MS (Brunet, 2014). After the current crash in the public debt, an essential turnover for the crisis should prove to be the effects related to the reduction of the private risk of a private leveraging which should spark a balance sheet recession. Despite accounting alchemy and financial engineering, the possible consequences of the risks taken are now beyond the current capabilities of the markets.

${ }^{4}$ See the internet for some common initiatives of transparency in debt of the Bank for International Settlements (2016), the OECD and the IMF: Joint External Debt Hub and the Quarterly External Debt Statistics. 
TABLE 1

THE EUROPEAN COMPETITION DEFICITS

\begin{tabular}{|c|c|c|c|c|c|c|c|c|c|}
\hline \multirow[b]{2}{*}{$\begin{array}{l}\text { MS Order: Official } \\
\text { by alphabet, grouped } \\
\text { by size and origin }\end{array}$} & \multicolumn{2}{|c|}{ Competitiveness } & \multicolumn{2}{|c|}{ Economic freedom } & \multicolumn{3}{|c|}{ Political conditions quality } & \multicolumn{2}{|c|}{ Competition Deficit } \\
\hline & $\begin{array}{l}\text { Score } \\
\text { (by 6) }\end{array}$ & $\begin{array}{l}\text { Rank: EU } \\
\text { Lisbon } \\
\text { Strategy/ } \\
\text { World }\end{array}$ & Score & $\begin{array}{l}\text { Rank: } \\
\text { European/ } \\
\text { World }\end{array}$ & Rule of law & \begin{tabular}{|c|}
$\begin{array}{c}\text { Political } \\
\text { stability } \\
\text { and absence } \\
\text { of violence }\end{array}$ \\
\end{tabular} & $\begin{array}{l}\text { Regula- } \\
\text { tory } \\
\text { quality }\end{array}$ & $\begin{array}{l}\text { Inverse of } \\
\text { economic } \\
\text { freedom }\end{array}$ & $\begin{array}{l}\text { Inverse of } \\
\text { regulato- } \\
\text { ry quality }\end{array}$ \\
\hline \multicolumn{10}{|c|}{ Western Large EU MS } \\
\hline Germany & 5,37 & $6 / 7$ & 71.2 & $12 / 23$ & 94.3 & 75.0 & 91.2 & -28.8 & -8.8 \\
\hline Spain & 4,59 & $18 / 33$ & 69.7 & $17 / 31$ & 84.8 & 58.2 & 82.0 & -30.3 & -18.0 \\
\hline France & 5,13 & $8 / 16$ & 65.4 & $25 / 48$ & 89.5 & 61.5 & 82.9 & -34.6 & -17.1 \\
\hline Italy & 4,31 & $25 / 48$ & 62.5 & $29 / 64$ & 60.0 & 56.3 & 74.1 & -37.5 & -25.9 \\
\hline United Kingdom & 5,19 & $9 / 13$ & 79.5 & $3 / 10$ & 93.3 & 61.1 & 98.0 & -20.5 & -2.0 \\
\hline \multicolumn{10}{|c|}{ Western Medium and Small EU MS } \\
\hline Belgium & 5,09 & $10 / 18$ & 71.5 & $10 / 20$ & 91.0 & 67.8 & 87.8 & -28.5 & -12.2 \\
\hline Denmark & 5,46 & $3 / 5$ & 79.2 & $4 / 11$ & 99.5 & 74.0 & 99.0 & -20.8 & -1.0 \\
\hline Ireland & 4,84 & $11 / 25$ & 82.4 & $1 / 3$ & 92.4 & 89.4 & 97.6 & -17.6 & -2.4 \\
\hline Greece & 4,04 & $23 / 71$ & 60.1 & $34 / 80$ & 67.6 & 63.0 & 71.1 & -39.9 & -28.9 \\
\hline Luxembourg & 4,96 & $5 / 21$ & 75.2 & $8 / 15$ & 95.7 & 99.5 & 98.5 & -24.8 & -1.5 \\
\hline Netherlands & 5,32 & $4 / 10$ & 76.8 & $6 / 13$ & 93.8 & 92.3 & 95.6 & -23.2 & -4.4 \\
\hline Austria & 5,13 & $7 / 17$ & 70.0 & $16 / 30$ & 97.1 & 70.7 & 94.6 & -30.0 & -5.4 \\
\hline Portugal & 4,43 & $16 / 40$ & 64.3 & $26 / 53$ & 82.9 & 82.2 & 81.0 & -35.7 & -19.0 \\
\hline Finland & 5,43 & $2 / 6$ & 74.8 & $9 / 16$ & 98.1 & 76.0 & 97.1 & -25.2 & -2.9 \\
\hline Sweden & 5,51 & $1 / 4$ & 70.4 & $14 / 27$ & 96.7 & 99.9 & 92.7 & -29.6 & -7.3 \\
\hline \multicolumn{10}{|c|}{ Central and Eastern Large and Medium EU MS } \\
\hline Bulgaria & 4,02 & $27 / 76$ & 62.9 & $28 / 59$ & 50.0 & 57.2 & 66.3 & -37.1 & -33.7 \\
\hline Hungary & 4,22 & $21 / 58$ & 67.2 & $23 / 43$ & 73.8 & 66.8 & 85.9 & -32.8 & -14.1 \\
\hline Poland & 4,33 & $24 / 46$ & 59.5 & $35 / 83$ & 59.0 & 54.3 & 69.3 & -40.5 & -30.7 \\
\hline Romania & 4,11 & $26 / 64$ & 61.5 & $30 / 68$ & 50.5 & 50.0 & 62.0 & -38.5 & -38.0 \\
\hline \multicolumn{10}{|c|}{ Newly Independent Small EU MS } \\
\hline Croatia & 4,03 & $-/ 72$ & 54.6 & 37 / 113 & 52.9 & 62.0 & 61.5 & -45.4 & -38.5 \\
\hline Czech R. & 4,67 & $15 / 31$ & 68.5 & $21 / 37$ & 73.3 & 70.2 & 79.5 & -31.5 & -20.5 \\
\hline Estonia & 4,56 & $12 / 35$ & 77.8 & $5 / 12$ & 80.5 & 71.2 & 92.2 & -22.2 & -7.8 \\
\hline Cyprus & 4,57 & $13 / 34$ & 71.3 & $11 / 22$ & 81.9 & 60.6 & 86.8 & -28.7 & -13.2 \\
\hline Latvia & 4,06 & $22 / 68$ & 68.3 & $22 / 38$ & 63.8 & 73.6 & 82.4 & -31.7 & -17.6 \\
\hline Lithuania & 4,30 & $20 / 53$ & 70.8 & $13 / 26$ & 61.9 & 74.8 & 81.5 & -29.2 & -18.5 \\
\hline Malta & 4.30 & $17 / 52$ & 66.0 & $24 / 47$ & 91.4 & $\ldots$ & 86.3 & -34.0 & -13.7 \\
\hline Slovenia & 4,55 & $14 / 42$ & 60.6 & $33 / 75$ & 75.2 & 82.7 & 72.7 & -39.4 & -27.3 \\
\hline Slovakia & 4,31 & $19 / 47$ & 68.7 & $20 / 35$ & 61.4 & 76.4 & 83.4 & -31.3 & -16.6 \\
\hline
\end{tabular}


TABLE 1 (continued)

THE EUROPEAN COMPETITION DEFICITS

\begin{tabular}{|c|c|c|c|c|c|c|c|c|c|}
\hline \multirow{2}{*}{$\begin{array}{c}\text { MS Order: Official } \\
\text { by alphabet, grouped } \\
\text { by size and origin }\end{array}$} & \multicolumn{2}{|c|}{ Competitiveness } & \multicolumn{2}{|c|}{$\begin{array}{l}\text { Economic } \\
\text { freedom }\end{array}$} & \multicolumn{3}{|c|}{$\begin{array}{c}\text { Political conditions } \\
\text { quality }\end{array}$} & \multicolumn{2}{|c|}{$\begin{array}{l}\text { Competition } \\
\text { Deficit }\end{array}$} \\
\hline & $\begin{array}{l}\text { Score } \\
\text { (by 6) }\end{array}$ & $\begin{array}{l}\text { Rank: EU } \\
\text { Lisbon } \\
\text { Strategy/ } \\
\text { World }\end{array}$ & Score & $\begin{array}{l}\text { Rank: } \\
\text { European/ } \\
\text { World }\end{array}$ & Rule of law & $\begin{array}{c}\text { Political } \\
\text { stability } \\
\text { and absence } \\
\text { of violence }\end{array}$ & $\begin{array}{l}\text { Regula- } \\
\text { tory } \\
\text { quality }\end{array}$ & $\begin{array}{l}\text { Inverse of } \\
\text { economic } \\
\text { freedom }\end{array}$ & $\begin{array}{l}\text { Inverse of } \\
\text { regulato- } \\
\text { ry quality }\end{array}$ \\
\hline \multicolumn{10}{|c|}{ Candidates to the $\mathbf{E U}$} \\
\hline Iceland & 4,80 & $-/ 26$ & & & & & & & \\
\hline Turkey & 4,16 & $-/ 61$ & 60.8 & $32 / 74$ & 55.7 & 25.5 & 57.6 & -39.2 & -42.4 \\
\hline \multicolumn{10}{|c|}{ Possible Candidates to the EU } \\
\hline Albania & 3,72 & $-/ 96$ & 63.3 & $27 / 56$ & 28.1 & 33.7 & 48.8 & -36.7 & -51.2 \\
\hline Bosnia \& H. & 3,53 & $-/ 109$ & 53.7 & $38 / 121$ & 37.1 & 28.4 & 34.6 & -46.3 & -65.4 \\
\hline FYR Macedonia & 3,95 & $-/ 84$ & 61.1 & $31 / 71$ & 43.8 & 25.0 & 52.7 & -38.9 & -47.3 \\
\hline Montenegro & 4,16 & $-/ 62$ & 55.9 & $\cdots / \cdots$ & 38.6 & 24.5 & 37.6 & -44.1 & -62.4 \\
\hline Kosovo & $\ldots$ & $\cdots$ & $\cdots$ & $\ldots / \cdots$ & 21.0 & 51.0 & $\cdots$ & $\cdots$ & $\cdots$ \\
\hline Serbia & 3,77 & $-/ 93$ & 54.0 & $\cdots / \cdots$ & 35.2 & $\cdots$ & 40.5 & -46.0 & -59.5 \\
\hline \multicolumn{10}{|c|}{ Neighbours of the EU } \\
\hline Norway & 5,17 & $-/ 14$ & 69.0 & $19 / 34$ & 99.0 & 91.8 & 90.7 & -31.0 & -9.3 \\
\hline Switzerland & 5,60 & $-/ 1$ & 79.7 & $2 / 9$ & 98.6 & 96.2 & 93.2 & -20.3 & -6.8 \\
\hline Russian F. & 4,15 & $-/ 63$ & 49.9 & $40 / 134$ & 19.0 & 23.6 & 33.7 & -50.1 & -66.3 \\
\hline Belarus & $\cdots$ & $\cdots$ & 44.7 & $41 / 150$ & 11.9 & 51.9 & 4.9 & -55.3 & -95.1 \\
\hline Ukraine & 3,95 & $-/ 82$ & 51.1 & $39 / 133$ & 27.1 & 37.0 & 32.7 & -48.9 & -67.3 \\
\hline Georgia & 3,81 & $-/ 90$ & 69.2 & $18 / 32$ & 32.9 & 21.6 & 44.4 & -30.8 & -55.6 \\
\hline Moldova & $\ldots$ & $\cdots$ & 58.4 & $36 / 89$ & 32.4 & 29.8 & 41.5 & -41.6 & -58.5 \\
\hline Israel & 4,80 & $-/ 27$ & 66.1 & $-/ 46$ & 70.0 & 14.4 & 78.0 & -33.9 & -22.0 \\
\hline Morocco & 4,03 & $-/ 73$ & 56.4 & $-/ 98$ & 53.3 & 34.6 & 47.8 & -43.6 & -52.2 \\
\hline Algeria & 3,95 & $-/ 83$ & 55.7 & $-/ 102$ & 31.0 & 19.2 & 27.8 & -44.3 & -72.2 \\
\hline \multicolumn{10}{|c|}{ For Reference } \\
\hline United States & 5,59 & $-/ 2$ & 80.6 & $-/ 5$ & 91.9 & 57.7 & 93.7 & -19.4 & -6.3 \\
\hline Canada & 5,33 & -19 & 80.2 & $-/ 7$ & 96.2 & 80.3 & 94.1 & -19.8 & -5.9 \\
\hline Japan & 5,37 & -18 & 72.5 & $-/ 17$ & 90.0 & 85.1 & 87.3 & -27.5 & -12.7 \\
\hline China & 4,74 & $-/ 29$ & 52.8 & $-/ 126$ & 45.2 & 33.2 & 46.3 & -47.2 & -53.7 \\
\hline
\end{tabular}

NOTE: Data for year 2015 or closer. Index $=100$ (maximum) is the reference value for columns 3, 5, 6 and 7. The Competition Deficit indexes of columns 8 and 9 have been obtained by subtracting 100 (maximum) from the values of the columns 3 and 7 . SOURCE: Elaboration on data from The World Economic Forum (2016) and from The World Bank (2016b and 2016c). 


\subsection{Structural disequilibrium IV: Low employment rate, high unemployment, inflexibility, over-cost due to overprotection and non-reform - The quality of the European labour markets}

There is a serious disequilibrium in the labour market in both the EU and the EA. This is because of a shared immobility of workers and a labour protection that limits flexibility. Thus, the effort to meet the conditions for being an optimal monetary area is faltering (Mundell, 2000).

The adjustments that are not possible to make in prices are transferred to quantities, into a low employment rate and high unemployment. In Figure 2 and Figure 6 we can see the clear correlation between the CA deficits and the unemployment rate. Most of the Mediterranean and in-transition MS have employment rates of lower than $60 \%$ and CA deficits. From the five MS with an employment rate over 70\%, four have a CA surplus. This is not the case for the United States (US) and the United Kingdom (UK. but their CA deficits are probably not connected, as is the EA with the labour market conditions, but it is the case with currency and other aspects related to global balances. The influence of the use of labour in competitiveness is great. In Europe, often the main obstacle to growth is regulation (OECD, 2015b). The persistent low employment rates and high

unemployment rates, as well as the non-reform of the labour market, are handicapping productivity and causing the rise of social costs.

\subsection{Structural disequilibrium V: Over-consumption vs. Under-investment}

The twin deficit and global imbalances analyses have established the links between aspects of the surplus and those of the deficit, between the US and China (Bergsten 2010). They also uncover the link between overconsumption in the US and underconsumption in China, as well as that between underinvestment in the US and overinvestment in China. The evaluation of the imbalances is dubious (Feldstein, 2008). 
FIGURE 6

\section{GOVERNANCE QUALITY IN A RANGE OF COUNTRIES}

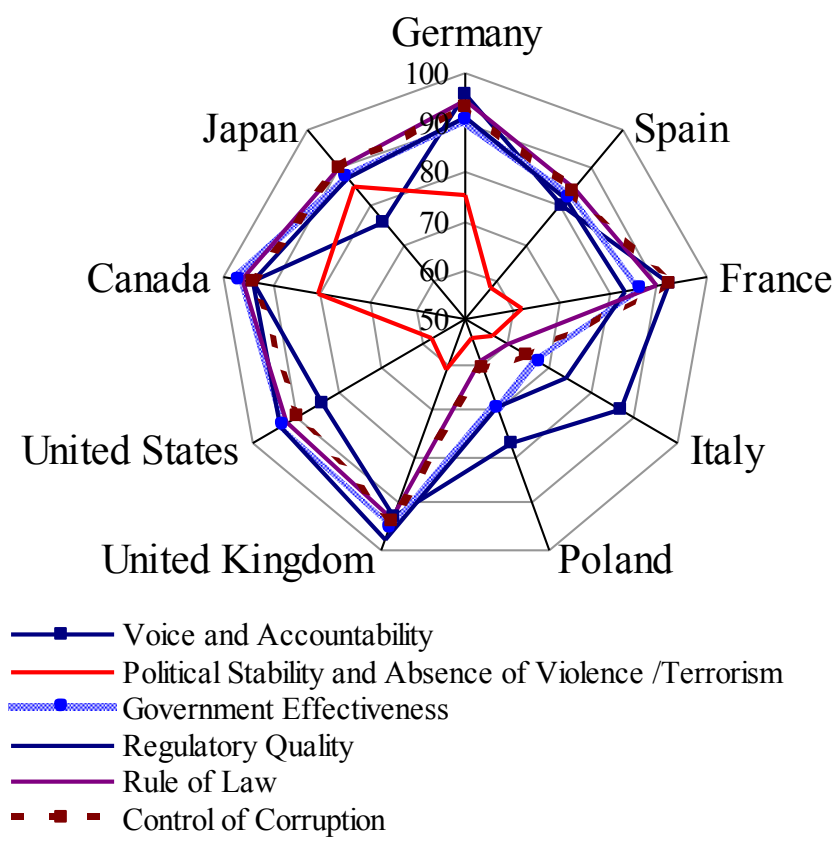

SOURCE: Elaboration on data from The World Bank (2016c). Data for year 2015 .

Are the EIB the result of overconsumption stimulated by credit facilities? In a macroeconomic approach, this is possible; the CA deficit allows higher expenditure in consumption, but also in investment. Nevertheless, the conclusions from statistics (Figure 2) are not clear: while having huge CA deficits, Spain also had high investment rates due to the simultaneity of enormous entries of foreign capital until at least 2008.

\section{The European imbalances: Competitiveness, quality of regulation and socio-economic models}

The EIB are the result of the capacity of the EU MS to compete in the internal and global market. Current and capital accounts, external and internal public debt, unemployment and other current and structural imbalances are all results of competitiveness. 


\section{FIGURE 7}

\section{EUROPEAN IMBALANCES AND COMPETITIVENESS}

Panel A. CA and PD in the EU MS

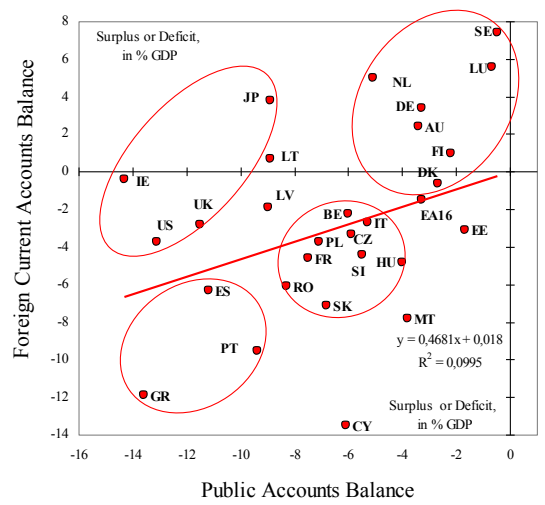

Panel B. CA and Economic Freedom in the EU MS

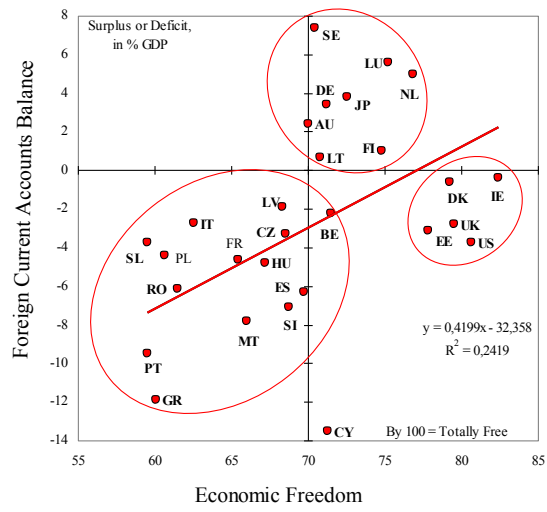

Panel C. CA and Competitiveness in the EU MS

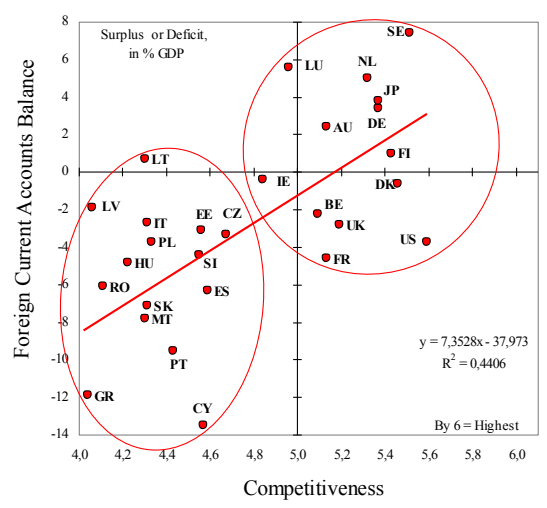

SOURCE: Data for year 2015 or closer. Elaboration on data from Eurostat (2016a), OECD (2016a), FedStats (2016) and The World Economic Forum (2016). 


\subsection{The European MS competitiveness: Conditions for competition}

In the contemporary advanced economies in which capital moves freely, institutions are the key variable. From productivity to living-standard, regulation both attracts and repulses capital, and with it the capacity to produce and distribute.

Competitiveness can be analysed considering:

- Institutions, infrastructure, macroeconomic stability, health and education, advanced education and training, goods market efficiency, labour market efficiency, financial market development, technological readiness, market size, business sophistication and innovation, as The World Economic Forum (2016) reports.

- Employment protection legislation, competition law and policy, product-market regulation, service-market regulation, administrative regulation, competitive intensity, public regulation, regulatory quality, as developed by OECD (2015a and 2016b) (see some of these aspects in Tables 1 and 2).

- Economic freedom, attractiveness of foreign capital, openness, tariffs, market access, entrepreneurship barriers, union density, creativity, country rating, public sovereign bonds spread and interest rate differential .

- Economic security, economic well-being, development goals, human development and other complex indexes.

- Public expenditure, state aid (all subsidies to enterprises. labour tax wedge, employment in public enterprises, administration and social services, public procurement, re-distribution (before and after taxes).

- Political freedom, rule of law index, corruption perception, governance conditions (The World Bank, 2016c).

- Values, popular voice and support, attitudes and other social aspects.

There is a link between economic freedom and living-standard (see Figure 7). In long-term dynamics, one favours the other. A decline in economic liberty in the first and second decades of the twentieth century is also clearly evident.

\subsection{The European MS regulatory quality}

Most of the characteristics of the MS in competition and competitiveness spring from regulation. Despite the common competition policy, competitive intensity is still varying from MS to MS. Denmark, Luxembourg, the United Kingdom, Ireland, Finland and Sweden rank between 99 and 90 in this index (out of 100, see Table 1). Belgium, France, Slovenia, Spain, Portugal rank between 90 and 80, followed by the in-transition MS. Regarding the rule of law, the range is broader but the order of the MS is similar. The evaluation of political stability, including the absence of violence, is quite different: the score swings between 99,9 for Sweden and 50 for Romania, and bigger MS such as Poland, Italy, and Spain score in the fifties. 


\section{FIGURE 8}

\section{EUROPEAN IMBALANCES AND LABOUR MARKET QUALITY}

Panel A. CA and Employment in the EU MS

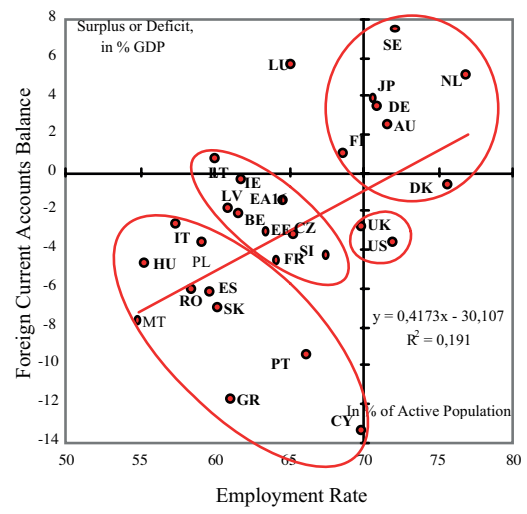

Panel B. CA and Unemployment in the EU MS

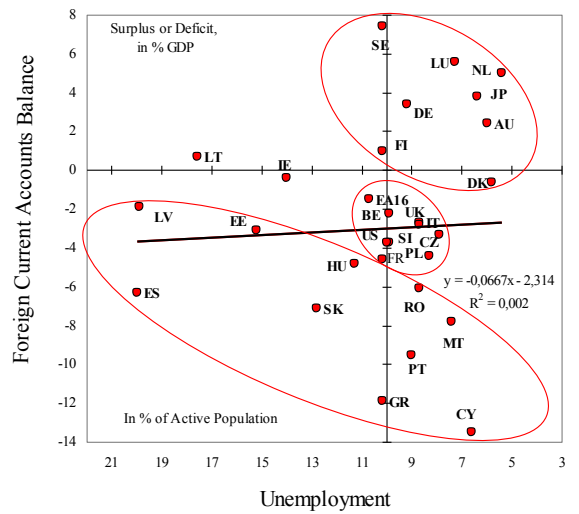

Panel C. Employment and Unemployment in the EU MS

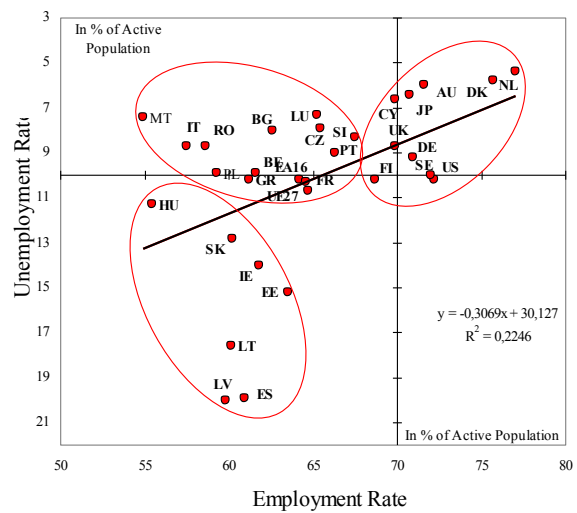

SOURCE: Data for year 2015 or closer. Elbaoration on data from Eurostat (2016a), OECD (2016c), US fedStat (2016) and World Economic Forum (2016). 
Quality of governance can be considered the fruit of the popular voice and accountability, political stability and absence of violence and terrorism, government effectiveness, regulatory quality and the rule of law. Figure 6 underlines the difficulties had by Poland, Spain and Italy. The rules of business are essential to competitiveness and performance. Thus the conditions and degree of economic freedom for the six bigger EU MS (see Table 2 for details) can be evaluated by the following points:

I. Starting a business: The selected countries ranks from 6 for the UK to 129 for Poland and 118 for Spain. The US has the highest score with no minimum capital, as does France.

II. Employing workers: In the labour market the benchmark has been set by the US, which ranks first in the world, and UK, which ranks at 21. Clearly we have a European problem: Spain, France and Germany rank 154, 144 and 137 respectively, with Poland at 78 and Italy at 56. In the

III. Combined aspects (difficulty of hiring, rigidity of hours, difficulty of firing, rigidity of employment, unwaged labour cost and cost of firing): Italy is the most flexible EU MS.

IV. Registering property: The UK and Spain hold the best EU ranks, especially in the number of procedures and on the time for completion.

V. Getting credit: The UK ranks first in the world and Germany third. Poland and Italy are neck-and-neck at 68 , France at 38 .

VI. Protecting investors: At 9th in the world, the UK is behind the US (5th). Spain and Germany are at 83.

VII. Paying taxes: This is quite an expensive obligation for enterprises, deducting $76 \%$ from the profit of Italian enterprises. The lowest rate of the countries considered is the US $(35,7 \%)$.

VIII. Trading across borders: Trade regulations are immense, and those that affect imports rather than exports are the largest and the worst. An interesting point: despite the common EU trade policy, the differences between the MS are great.

IX. Enforcing contracts: The empire of the rule of law is key for business: the US ranks at 8 in the world, France and Germany rank 14 and 15 respectively, and the UK is the $24^{\text {th }}$.

X. Closing a business: This can be the ruin of an investment. In Poland, the worst MS considered, the recovery rate is $27,8 \%$.

The different aspects of economic regulation, the rule of law, conditions of politics and economic governance all bring the quality of regulation into line and are essential for contemporary competitiveness and performance. All these aspects show that the structural and institutional causes of the EIB are deeply-rooted, as has been attested in the previous Tables 1 and 2, as well as in Figure 6. The next figures 7 and 8 , test some aspects of the links between the EIB and regulation quality and between competitiveness and employment. 
CA are intimately connected to economic freedom. The Nordic and Central group of the EU ranks highly in these matters, as do the UK and the US. Greece and Portugal are in the worst position. Spain and Portugal perform better regarding business rules. Panel B of Figure 7 deals with competitiveness (as reported by The World Economic Forum, 2016) and trade balance: the CA surplus MS group has a high rate of competitiveness, while the deficit MS group is performing badly.

Figure 8 deals with the links between CA and labour-market quality. The highest employment rates produce CA surpluses. The exceptions are the UK and the US. Inversely, an employment rate below $70 \%$ of the active population is connected to CA deficits. Here the impact of CA on employment is confirmed. Panel B deals with unemployment: the positive CA balances are in the MS with lower unemployment rates. The dispersion of the CA-deficit MS in unemployment reduces the general correlation between these two indicators.

Employment versus unemployment is the theme of Panel C: the surplus group of MS has higher employment rates and lower unemployment rates, as do the US and Japan. All of the MS with an unemployment rate above the EU average have employment rates of below 65 per cent.

\subsection{The European socioeconomic Model(s) and the EIB}

Unity versus diversity, the MS versus the EU: despite certain common economic constitutions (Brunet, 2010) and EU policies -essential for rules of competitionthe quality of regulation differs greatly among EU MS, even among the EU15. Is there one model or many to be found in the EU? What should be truly European is the emphasis on solidarity, the protection of the labour market, the welfare state synthesized in a social security system managed by the MS governments.

Despite the common market, policies and institutions, the quality of regulation is still a matter of national determination. In this sense, the analysis of the EIB shows the existence of some common paths taken between MS in diverse areas:

- The Nordic, Baltic, Atlantic and/or Central European MS: Germany, the Netherlands, Denmark, Sweden, Finland and Austria move as one in indicators and performance, sometimes in rules (see Table 2).

- The UK: Looks different in many features, in some ways close to the US.

- The Mediterranean MS: Greece, Portugal and Spain, also Italy and France in several aspects.

-The in-transition MS: small and newly-independent European countries, most of them outside the euro, and Poland in some matters.

The political orientation of the MS and the cautiousness of their governments explain part of the differences between the MS EIB. Some in-transition MS have smaller EIB than can be supposed. Perhaps not being members of the EA also offers them an additional degree of liberty to adjust to the exchange rate. 
FIGURE 9

THE CEASING OF THE CATCHING-UP PROCESS BETWEEN AMERICA AND EUROPE

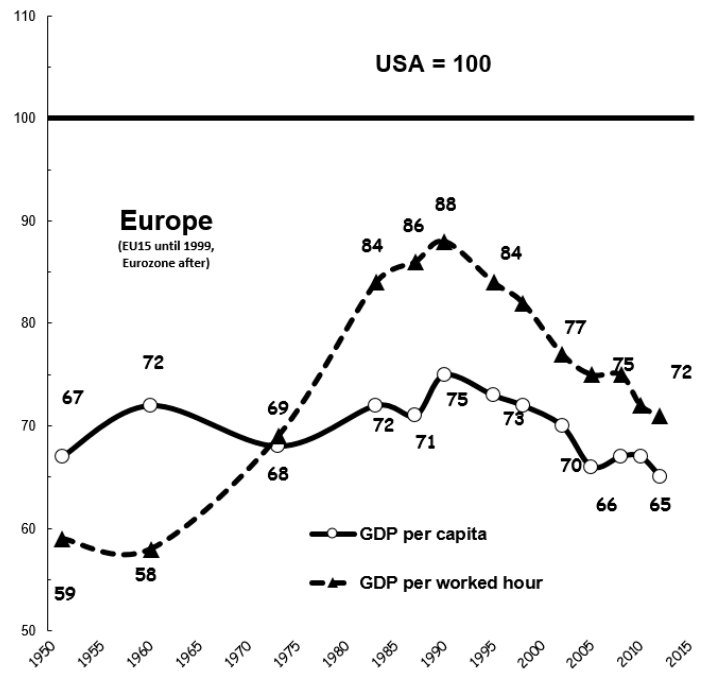

SOURCE: Elaboration on data from Council of Economic Advisers (2016), Eurostat (2016) and OECD (2016a).

5. The European imbalances: Economic policy in a context of non-optimal monetary union and of crisis - The crash of the euro

\subsection{The European monetary union: From success to crash}

The EMU has, according to Sinn (2014):

- Limited protection and increased competition in the internal market.

- Favoured the EIB.

- Facilitated the balance of the EIB by credit.

- Reduced the effective degrees of liberty for the MS in economic policy, especially in trade, financial and fiscal aspects.

Inside the EMU, the EIB have grown through their financing by credit. There is a strong link between the EMU and the EIB. The strengthening of integration by the EMU has generated different answers to the question among the MS depending on their imbalances and capabilities for adjustment or ability to reform. When adjustments failed, the EMU offered the means to rebalance the EIB, financing through debt. Governments, enterprises and households of the deficit MS made a profit off the EMU. The monetary policy implemented by the European Central Bank gave a great liquidity at a real negative interest rate. From summer 2007 onwards, the global financial crush has sharpened this policy and its effects: a cushion for the growing EIB (OECD, 2016b). 
TABLE 2

ECONOMIC RULES IN A RANGE OF COUNTRIES

\begin{tabular}{|c|c|c|c|c|c|c|c|c|c|}
\hline & Unit & Germany & Spain & France & Italy & Poland & U.K. & U.S. & Japan \\
\hline Population & million & 82.4 & 44.1 & 61.4 & 58.9 & 38.1 & 60.6 & 299.0 & 127.6 \\
\hline$G D P$ & $\begin{array}{c}\text { year per capita } € \\
P P P\end{array}$ & 26,700 & 24,000 & 26,500 & 24,300 & 12,400 & 27,900 & 36,300 & 26,700 \\
\hline Main legal origin & & German & French & French & French & German & English & English & German \\
\hline $\begin{array}{l}\begin{array}{c}\text { Global economic } \\
\text { freedom }\end{array} \\
\text { (summary of points } \\
1 \text { to } 10 \text { ) }\end{array}$ & World rank & 25 & 62 & 31 & 78 & 72 & 6 & 4 & 15 \\
\hline $\begin{array}{l}\text { 1. Starting a } \\
\text { business }\end{array}$ & World rank & 71 & 118 & 12 & 65 & 129 & 6 & 4 & 44 \\
\hline Procedures & Number & 9 & 10 & 5 & 9 & 10 & 6 & 56 & 8 \\
\hline Time & Days & 18 & 47 & 7 & 13 & 31 & 13 & 6 & 23 \\
\hline Cost & $\%$ of income & 5,7 & 15,1 & 1,1 & 18,7 & 21,2 & 0,8 & 0,7 & 7,5 \\
\hline Minimum capital & & 42,8 & 13,7 & 0,0 & 9,8 & 196,8 & 0,0 & 0,0 & 0,0 \\
\hline $\begin{array}{l}\text { 2. Dealing with } \\
\text { licenses }\end{array}$ & World rank & 16 & 46 & 17 & 78 & 156 & 54 & 24 & 32 \\
\hline Procedures & Number & 12 & 11 & 13 & 14 & 30 & 19 & 19 & 15 \\
\hline Time & Days & 100 & 233 & 137 & 257 & 308 & 144 & 40 & 177 \\
\hline Cost & $\%$ of income & 63,1 & 64,9 & 24,9 & 138,2 & 159,8 & 64,6 & 13,4 & 17,8 \\
\hline $\begin{array}{l}\text { 3. Employing } \\
\text { workers }\end{array}$ & World rank & 137 & 154 & 144 & 56 & 78 & 21 & 1 & 17 \\
\hline Difficulty of hiring & & 33 & 78 & 67 & 33 & 11 & 11 & 0 & 0 \\
\hline Rigidity of hours & Index & 60 & 60 & 60 & 40 & 60 & 0 & 0 & 20 \\
\hline Difficulty of firing & $0-100$ & 40 & 30 & 40 & 40 & 40 & 10 & 0 & 30 \\
\hline $\begin{array}{l}\text { Rigidity of } \\
\text { employment }\end{array}$ & & 44 & 56 & 56 & 38 & 37 & 7 & 0 & 17 \\
\hline Nonwage labor cost & $\%$ of salary & 19 & 33 & 47 & 37 & 21 & 11 & 8 & 13 \\
\hline Firing cost & Weeks of salary & 69 & 56 & 32 & 2 & 13 & 22 & 0 & 4 \\
\hline $\begin{array}{l}\text { 4. Registering } \\
\text { property }\end{array}$ & World rank & 47 & 42 & 159 & 49 & 81 & 19 & 10 & 48 \\
\hline Procedures & Number & 4 & 4 & 9 & 8 & 6 & 2 & 4 & 6 \\
\hline Time & Days & 40 & 18 & 123 & 27 & 197 & 21 & 12 & 14 \\
\hline Cost & $\%$ of property value & 5,2 & 7,1 & 6,1 & 0,6 & 0,5 & 4,1 & 0,5 & 5,0 \\
\hline 5. Getting credit & World rank & 3 & 13 & 36 & 68 & 68 & 1 & 7 & 13 \\
\hline $\begin{array}{l}\text { Strength of legal } \\
\text { rights }\end{array}$ & Index 0-10 & 8 & 6 & 6 & 3 & 4 & 10 & 7 & 6 \\
\hline $\begin{array}{l}\text { Depth of credit } \\
\text { information }\end{array}$ & Index 0-6 & 6 & 6 & 4 & 5 & 4 & 6 & 6 & 6 \\
\hline $\begin{array}{l}\text { Public registry } \\
\text { coverage }\end{array}$ & $\%$ of adults & 0,7 & 4,9 & 24,8 & 11,0 & 0,0 & 0,0 & 0,0 & 0,0 \\
\hline $\begin{array}{l}\text { Private bureau } \\
\text { coverege }\end{array}$ & $\%$ of adults & 98,1 & 8,3 & 0,0 & 71,5 & 51,5 & 84,6 & 100,0 & 68,3 \\
\hline
\end{tabular}


TABLE 2 (continued)

ECONOMIC RULES IN A RANGE OF COUNTRIES

\begin{tabular}{|c|c|c|c|c|c|c|c|c|c|}
\hline & Unit & Germany & Spain & France & Italy & Poland & U.K. & U.S. & Japan \\
\hline Population & million & 82.4 & 44.1 & 61.4 & 58.9 & 38.1 & 60.6 & 299.0 & 127.6 \\
\hline$G D P$ & $\begin{array}{l}\text { year per capita } \\
\quad € P P P\end{array}$ & 26,700 & 24,000 & 26,500 & 24,300 & 12,400 & 27,900 & 36,300 & 26,700 \\
\hline Main legal origin & & German & French & French & French & German & English & English & German \\
\hline $\begin{array}{l}\text { Global economic } \\
\text { freedom } \\
\text { (summary of points } \\
1 \text { to } 10 \text { ) }\end{array}$ & World rank & 25 & 62 & 31 & 78 & 72 & 6 & 4 & 15 \\
\hline $\begin{array}{l}\text { 6. Protecting } \\
\text { investors }\end{array}$ & World rank & 83 & 83 & 64 & 51 & 33 & 9 & 5 & 12 \\
\hline Extent of disclosure & & 5 & 5 & 10 & 7 & 7 & 10 & 7 & 7 \\
\hline $\begin{array}{l}\text { Extent of director } \\
\text { liability }\end{array}$ & Index 0-100 & 5 & 6 & 1 & 4 & 2 & 7 & 9 & 6 \\
\hline $\begin{array}{l}\text { Ease of shareholder } \\
\text { suits }\end{array}$ & & 5 & 4 & 5 & 6 & 9 & 7 & 9 & 8 \\
\hline $\begin{array}{l}\text { Strength of investor } \\
\text { protection }\end{array}$ & & 5,0 & 5,0 & 5,3 & 5,7 & 6,0 & 8,0 & 8,3 & 7,0 \\
\hline 7. Paying taxes & World rank & 67 & 93 & 82 & 122 & 125 & 12 & 76 & 105 \\
\hline Payments & Number per year & 16 & 8 & 23 & 15 & 41 & 8 & 10 & 13 \\
\hline Time & Hours per year & 196 & 298 & 132 & 360 & 418 & 105 & 325 & 350 \\
\hline Total tax rate & $\%$ of profit & 50,8 & 62,0 & 66,3 & 76,2 & 38,4 & 35,7 & 46,2 & 52,0 \\
\hline $\begin{array}{l}\text { 8. Trading across } \\
\text { borders }\end{array}$ & World rank & 10 & 47 & 25 & 62 & 40 & 27 & 15 & 18 \\
\hline Documents to export & Number & 4 & 6 & 4 & 5 & 5 & 4 & 4 & 4 \\
\hline Time to export & Days & 7 & 9 & 11 & 20 & 17 & 13 & 6 & 10 \\
\hline Cost to export & US\$ per container & 740 & 1000 & 1028 & 1291 & 834 & 940 & 960 & 989 \\
\hline Documents to import & Number & 5 & 8 & 5 & 5 & 5 & 4 & 5 & 5 \\
\hline Time to import & Days & 7 & 10 & 12 & 18 & 27 & 13 & 5 & 11 \\
\hline Cost to import & US\$ per container & 765 & 1000 & 1148 & 1291 & 834 & 1267 & 1160 & 1047 \\
\hline $\begin{array}{l}\text { 9. Enforcing } \\
\text { contracts }\end{array}$ & World rank & 15 & 55 & 14 & 155 & 68 & 24 & 8 & 21 \\
\hline Procedures & Number & 33 & 39 & 30 & 41 & 38 & 30 & 32 & 30 \\
\hline Time & Days & 394 & 515 & 331 & 1210 & 830 & 404 & 300 & 316 \\
\hline Cost & $\%$ of claim & 11,8 & 17,2 & 17,4 & 29,9 & 10,0 & 23,4 & 9,4 & 22,7 \\
\hline $\begin{array}{l}\text { 10. Closing a } \\
\text { business }\end{array}$ & World rank & 29 & 17 & 32 & 25 & 88 & 10 & 18 & 1 \\
\hline Time & Years & 1,2 & 1,0 & 1,9 & 1,8 & 3,0 & 1,0 & 1,5 & 0,6 \\
\hline Cost & $\%$ of estate & 8 & 15 & 9 & 22 & 22 & 6 & 7 & 4 \\
\hline Recovery rate & Cents on the dollar & 53,4 & 76,9 & 47,4 & 61,8 & 27,8 & 84,6 & 75,9 & 92,6 \\
\hline
\end{tabular}

SOURCE: Elaboration on data from The World Bank (2016b). Data for year 2016 or closer. 
The bubbles in finance, the stock market and housing have burst but not deflated, in contradiction with a limited consumption price inflation and a deflation of real prices of manufacture (IMF, 2016b). Thus combined with the crisis, the EIB are fomenting distrust among the deficit MS, especially those with huge bubbles in debt. Now the different economic imbalances, imbalances, deficits and gaps in the quality of regulation and performances of the MS are putting confidence in the euro at risk.

The financial crisis has provoked:

- A reduction in CA imbalances, both of the surpluses and of the deficits, in part due to the reduction of trade (see Figure 2).

- A generalization and a huge growth of the PD and in debt (see and Figures 2 and 4).

- Growth in structural imbalances in the labour market (see Figure 2).

- A cessation of the liberalization process (see Tables 1 and 2, and Figure 9).

An inability to compete and to reform is evident in some MS. In taking refuge in financial facilities, most of the MS overlooked the most prudential rules, as well as the EU Stability and Growth Pact.

\subsection{The crash of some MS: EIB and non-reform syndrome - The end of the fiesta and the sickness of Europe}

Greece, Spain, Portugal, Italy, France, the United Kingdom, Hungary, Bulgaria... how does one rank the problems and the rating of distrust held by each one? Due to the EMU, after the euro crush PIGS make up the entire EA MS and even the entire EU (European Commission. Directorate General for Economic and Financial Affairs, 2016).

The previous success of certain MS with considerable structural limitations is due to the beneficial position of being a member of the EA (Brunet, 2016). All the elements of a fiesta were at hand: credit, foreign investments, immigration, structural funds. The crash was foreseen (OECD, 2016b). In the new EMU and the context of crisis, the PD of the deficit EU MS has grown due to structural deficits which limit revenues, pressures on the growing expenditures, and to sloppy fiscal and labour policies.

Regarding the EMU and the growing EIB, the convergence between MS is turning into divergence between the surplus Nordic and Central Europe countries and the deficit countries of the Mediterranean and Eastern Europe. Some social and ideological conditions continue to instil a fear of competition, change and structural reforms that make it impossible for the governments to adjust (see Figure 9). There is the market which balances and the social security which pays the cost: in the labour market, instead of price adjustment (salaries. the adjustment is made in quantities (rates of employment and unemployment) (see Figure 2 and Panel C of Figure 8). 
The risk is the conversion of a debt crisis into a fiscal crisis making way for an epoch of depression.

\subsection{The European economic governance under the euro crisis and the growing EIB}

Surveillance, governance, cooperation, co-responsability, pact, interest and other pretty words in economic policy can be bandied about. But the form of the EU is quite complex and so for certain actions, a long time and a huge cost are required. While perhaps not the case for the surplus and advanced EU MS, for the deficit MS (as well as for the EU in general), the current catastrophic situation could devolve into a desperate one. Instead of this, some advances in European economic governance should be made soon, in coherence with the path of the EU.

Indeed, any other way would be difficult. Nevertheless, as with the problems, the solutions to EIB and to the euro crash have to be structural: reform in the European economy can help the EU to confront the challenges of competitiveness, delocation and welfare due to ageing, economic change and globalization. Between stabilization and reform, European economic governance has come face to face with considerable demands. All the glory and all the limitations of economics and politics are to be found in the new European economic governance.

\section{Conclusion. The need for competitiveness, for structural reforms and for Europe}

Europessimism is dominant. It is enjoying hegemony in economics due to the euro crisis. Moreover, it prevails in politics due to the complexity of the EU system and the difficult to reduce its democratic and administrative deficits. Caused by structural limitations and careless policies, and balanced with financial payments, the EIB of the EU deficit MS have provoked a crisis in the sovereign debt of certain Mediterranean MS. However, others could follow... if the new powers of European governance are not able to guide the MS and the markets in a fair and equitable way and if economic growth does not follow. Stabilization is the condition for the road to high rates of competitiveness. Nevertheless, growth, reform, employment and liberalization are necessary to preserve the European socio-economic model which mixes competition and solidarity, productivity and wellbeing. So eurooptimism shall be dominant. Europe will persist, proving not to be a lost paradise but instead offering the European citizen and the world the virtues of the last utopia. 


\section{References}

[1] AMECO [by European Commission. Directorate-General for Economic and Financial Affairs]. 2016. AMECO Data Base. Retrieved on 23th January and on $3^{\text {rd }}$ April 2016 from http://ec.europa.eu/economy_finance/ameco.

[2] ANONYMOUS (2010). "Prospects for real and financial imbalances and a global rebalancing". ECB Monthly Bulletin, April, pp. 91-100.

[3] BANK FOR INTERNATIONAL SETTLEMENTS (2016). "Joint BIS-IMF-OECD-World Bank statistics on external debt". Retrieved on $7^{\text {th }}$ May 2016 from http://www.bis.org.

[4] BLANCHARD, O. and MILESI-FERRETTI, G. M. (2009). "Global Imbalances: In Midstream?" IMF Staff Position Note, No. 29, December 22.

[5] BERGSTEN, C. F. (2010). "How Washington Can Prevent the Next Crisis". Foreign Affairs, vol. 88, No 6, November/December, pp. 20-38.

[6] BRUNET, F. (2010). Curso de Integración Europea, $2^{\text {nd }}$ ed., Madrid, Alianza Editorial.

[7] BRUNET, F. (2012). "The American and European Challenges. Financial Stabilization and Structural Reforms to Avoid Collapse, Limit Recession, and Promote Competitiveness", in Finn Laursen (ed.), The EU and the Political Economy of Transatlantic Relations, Brussels, P.I.E. Peter Lang, pp. 59-80.

[8] BRUNET, F. (2013). "Stability and Competitiveness in the European Monetary Union". Ekonomiaz, No. 82, pp. 82-107.

[9] BRUNET, F. (2014). "Crisis económica y modelo social: análisis de algunos retos de Europa y de España en la Gran Recesión”, in José Ignacio García Ninet (dir.) and Pepa Burriel Rodríguez-Diosdado (coord.), El impacto de la gran crisis mundial sobre el Derecho del Trabajo y de la Seguridad Social. Su incidencia en España, Europa y Brasil, 2008-2014, Barcelona, Fundació laCaixa-Editorial Atelier, pp. 63-91.

[10] BRUNET, F. (2015). "Convergence and divergences in the European economy: Rebalancing and being competitive in a non-optimal monetary union", in Francis Querol (coord.), De quelques aspects de l'Unión économique et monétaire européenne, Toulouse, Presses de l'Université de Toulouse 1 Capitole, pp. 13-51.

[11] BRUNET, F. (2016). "Capítulo 3. Economía de la europeriferia”, in Evangelina Aranda García (dir.). and Juan R. Cuadrado Roura and F. Javier Casares Ripol (cols.), Política Económica. Un contexto de crisis, recuperación e incertidumbre, Navarra, Thompson Reuters-Civitas Aranzadi, pp. 63-93.

[12] COUNCIL OF ECONOMIC ADVISERS (2016). Economic Report of the President Transmitted to the Congress, February 2016, Together with the Annual Report of the Council of Economic Advisers, Washington, DC, Government Printing Office.

[13] CONFERENCE BOARD AND GRONINGEN GROWTH AND DEVELOPMENT CENTRE (2016). "Total Economy Database". Retrieved on $2^{\text {nd }}$ February 2016 from http://www.conference-board.org/economics.

[14] ECONOMIST - INTELLIGENCE UNIT, THE (2010). "Time to Rebalance. A Special Report on America's Economy", The Economist, April $3^{\text {rd }}, 16 \mathrm{pp}$.

[15] EUROPEAN CENTRAL BANK (2016). Statistical Data Warehouse. Retrieved on $11^{\text {th }}$ January and $3^{\text {rd }}$ and $4^{\text {th }}$ June 2016 from $h t t p: / / s d w . e c b . e u r o p a . e u$.

[16] EUROPEAN COMMISSION. Directorate-General for Economic and Financial Affairs (2008). "EMU@10: successes and challenges after 10 years of economic and monetary union", European Economy, No. 2. 
[17] EUROPEAN COMMISSION. Directorate-General for Economic and Financial Affairs (2016). Quarterly Report on the Euro Area, Vol. 15, No. 1. Retrieved on $11^{\text {th }}$ June 2016 from http://ec.europa.eu/economy_finance/publications/eeip/ip024_en.htm.

[18] EUROPEAN UNION (2010). "Council Regulation (EU) No. 407/2010 of 11 May 2010 establishing a European financial stabilisation mechanism", Official Journal of the European Union, No. L 118, 12 May, pp. 1-4.

[19] EUROSTAT (2016). Database. Retrieved on $4^{\text {th }}$ and $27^{\text {th }}$ February and on 30th May 2016 from http://epp.eurostat.ec.europa.eu.

[20] FEDSTATS (2016). Statistical Programs of the United States Government. Retrieved on $14^{\text {th }}$ March 2016 from http://fedstats.gov.

[21] FELDSTEIN, M. (2008). "Resolving the Global Imbalance: The Dollar and the U.S. Saving Rate". Journal of Economic Perspectives, Vol. 22, No. 3, pp. 113-125.

[22] INTERNATIONAL MONETARY FUND (2016a). World Economic Outlook, Washington, DC, International Monetary Fund.

[23] INTERNATIONAL MONETARY FUND (2016b). World Financial Instability Report, Washington, DC, International Monetary Fund.

[24] MUNDELL, R. (2000). "The Euro and the Stability of the International Monetary System", in Robert Mundell and Armand Clesse (eds.), The Euro as a Stabilizer in the International Economic System, New York, Springer, pp. 57-84.

[25] OECD (2016a). Main Economic Indicators. Retrieved on 22th June and $11^{\text {th }}$ September 2015, and $3^{\text {rd }}$ June 2016 from http://www.oecd.org/dataoecd.

[26] OECD (2016b). "European Union”, OECD Economic Surveys, Paris, OECD.

[27] OECD (2015a). The OECD Glossary of Statistical Terms. Retrieved on $25^{\text {th }}$ November 2015 from http://stats.oecd.org/glossary.

[28] OECD (2015b). Going for Growth, Paris, OECD.

[29] SINN, H.-W. (2014). The Euro Trap. On Bursting Bubbles, Budgets, and Beliefs, Oxford, OUP.

[30] STANDARD \& POOR'S (2016). Ratings. Retrieved on 15 ${ }^{\text {th }}$ May 2016 from http:// www2.standardandpoors.com.

[31] WORLD BANK, THE (2016a). Quarterly External Debt Statistics, Washington, DC, World Bank.

[32] WORLD BANK, THE (2016b). Doing Business 2016, Washington, DC, World Bank and International Finance Corporation.

[33] WORLD BANK, THE (2016c). Worldwide Governance Indicators. Retrieved on 23th April 2016 from http://www.info.worldbank/governance.

[34] WORLD ECONOMIC FORUM, THE (2016). The Global Competitiveness Report 2015-2016, Davos, The World Economic Forum. 